\title{
Preliminary hydrochemical characteristics of an urban lake restored using a sequential application of iron and aluminum coagulants
}

\author{
Anna Płachta \\ Department of Water Protection Engineering and Environmental Microbiology, Faculty of Geoengineering, \\ University of Warmia and Mazury in Olsztyn, 1 Prawocheńskiego St., Olsztyn, Poland \\ anna.plachta@uwm.edu.pl
}

\begin{abstract}
A study was carried out on Lake Mielenko in Kartuzy. It is a small and shallow waterbody (7.8 ha, max. depth 1.8 $\mathrm{m})$, whose morphometric conditions qualify it as a polymictic lake (the first lake in a river - lake system). Before the reclamation began, the lake was characterized by a high concentration of chlorophyll-a (16.4 $\mathrm{mg} \mathrm{m}^{-3}$ in spring to $33 \mathrm{mg}^{-3}$ in summer) and low visibility. The purpose of the study was to determine the impact of the first stage of restoration of Lake Mielenko by phosphorus inactivation using a combination of aluminum and iron coagulants (PIX and PAX). After coagulant dosing into the lake, a significant decrease in chlorophyll-a was observed, which resulted in improving water transparency in the lake and decreasing concentrations of both nutrients (nitrogen and phosphorus). The total concentration of nutrients was dominated by organic forms (constituting 71-95\%). Maximum nutrient concentrations were $0.273 \pm 0.01 \mathrm{mg} \mathrm{P} \mathrm{L}^{-1}$ and $5.52 \pm 0.1 \mathrm{mg} \mathrm{N} \mathrm{L}^{-1}$ (in the summer period before the restoration activities were performed).
\end{abstract}

Key words: restoration, Lake Mielenko, coagulant, nutrients, chlorophyll-a

\section{Introduction}

Eutrophication, otherwise known as aging or an increase in the fertility of water, is a natural, usually long-term process taking place in every lake. However, anthropogenic activities significantly accelerate this process. The main reason for the increasing fertility of lakes is nutrient loading (mainly nitrogen and phosphorus). The constant increase in nutrient concentration causes a strong development of phytoplankton and macrophytes (Jachniak 2013, Hikey, Gibbs 2009). It is assumed that one kilogram of phosphorus generates a phytoplankton mass equal to one ton (Kajak 2001). Since pollutants enter lakes along with surface runoff from the catchment area or through direct sewage discharge, water bodies located near agricultural, industrial and urban areas are under the highest pressure. Protective methods are used to reduce the inflow of pollution and improve the quality of water and even, to some extent, reverse the eutrophication process. The condition of some lakes is so serious that despite cutting off pollution inflows from the catchment, the lake is alimented with nutrients stored in bottom sediments as a result of the so-called internal loading process. In this case, it is necessary to take restoration measures (technical, chemical or biological) within the lake basin (Gawrońska et al. 2003).

It is estimated that $30 \%$ of lakes in Poland are degraded and they require remedial actions, including restoration (Siwek 2013).

One commonly used method of restoration is the removal of mineral phosphorus from the water column and its permanent deactivation in bottom sediment, which helps to inhibit secondary phosphorus pollution (internal loading). The most common preparations are salts of metals such as aluminum, iron and calcium (Gawrońska et al. 2003).

The phosphorus inactivation method is used for lakes which, despite the protective measures applied, still show high water fertility as a result of the release 
of nutrients from bottom sediments. In practice, this mainly applies to shallow polymictic lakes (Gawrońska et al. 2003). Phosphorus inactivation is one of the cheapest reclamation methods with high efficiency in removing phosphorus (mainly mineral forms) and limiting internal supply. By using aluminum and iron salts, primary production is reduced and the clarity of the water is improved. The disadvantage of this method is maintaining the appropriate $\mathrm{pH}$ and oxygenation of the water. As a result of inadequate environmental conditions, aluminum and iron ions become toxic and affect the physical changes of fish and limit the ability to uptake phosphorus by plant roots (Wolter 2010).

The aim of the study was to determine the impact of the first stage of restoration of the city lake with the use of iron (PIX) and aluminum (PAX) coagulants on water quality and to determine the condition of the lake before the start of restoration activities.

\section{Materials and methods}

An example of a lake on which the method described was used is Lake Mielenko located in Kartuzy $\left(54^{\circ} 19^{\prime} 55^{\prime \prime} \mathrm{N}, 18^{\circ} 10^{\prime} 55^{\prime \prime} \mathrm{E}\right)$. It is the smallest and the highest placed lake in the Klasztorna Struga river-lake system. The area of the water body is only 7.8 ha and the maximum depth is $1.9 \mathrm{~m}$.

Lake Mielenko is located in northern Poland, in the western part of the city of Kartuzy (Fig. 1) at an altitude of $204 \mathrm{~m}$ above sea level. Detailed morphometric data are summarized in tab. 1 . Since the lake is the first link in the river-lake system, it was decided to restore the lake to minimize pollution reaching other lakes.

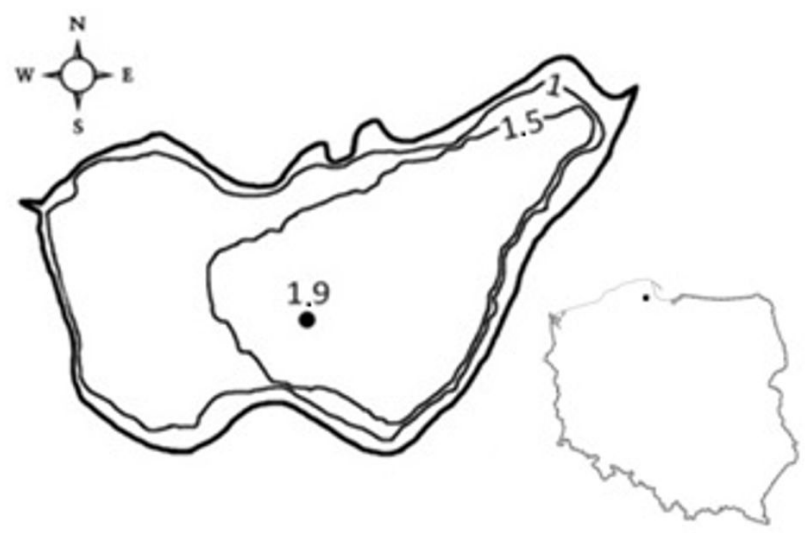

Fig. 1 Location and bathymetric map of Lake Mielenko (Department of Water Protection Engineering and Environmental Microbiology- unpublished details)
Lake Mielenko is classified as a shallow polymictic lake due to its morphometry. A depth index of 0.68 indicates that the lake basin is hemispheric. The lake is poorly embedded in the ground $\left(\mathrm{H}_{\mathrm{rel}}-0.0068\right)$. The shoreline is slightly developed $(\mathrm{K}-1.3)$, with a length of $1314 \mathrm{~m}$ (Table 1). The shores of the lake are relatively flat, sometimes marshy. The unfavorable morphometry of the lake and its location in the municipal catchment have a significant impact on progressive eutrophication.

Lake Mielenko is a throughflow waterbody. A small forest stream flows into the lake located in the northwestern part of the lake. The outflow is located on the north-eastern shore and drains water to Lake Karczemne.

During the research, it was determined that Lake Mielenko is strongly eutrophic and in terms of some parameters, even hypertrophic. At the beginning of March, the lake was recultivated with the use of iron (PIX 111) and aluminum (PAX 18) coagulants. The doses of coagulants were appropriately selected and amounted to: $2,485 \mathrm{~kg}$ of aluminum coagulant and 2,260 kg of iron coagulant. The preparations were distributed once, using the surface method from the deck of vessels. GPS was also used to obtain the most even distribution of the coagulant over the entire lake surface.

The research was conducted monthly from April 2019 to May 2020. In March 2020, lake restoration began by phosphorus inactivation using the sequential application of iron salts (PIX 111) and aluminum salts (PAX 18). Water samples were taken from $1 \mathrm{~m}$ deep from the central part of the lake. During the study, nutrients (forms of nitrogen- $\mathrm{N}-\mathrm{NO}_{3}, \mathrm{~N}-\mathrm{NH}_{4}$, Norg and TN (Fig. 3) and phosphorus - $\mathrm{P}_{-} \mathrm{PO}_{4}$, Porg and TP) (Fig. 2), chlorofil-a (Fig. 4) and water transparency were determined (Fig. 5). All analyses were conducted in accordance with the methodology used in hydrochemical research by Hermanowicz et al. (1999). Phosphate concentration $\left(\mathrm{P}_{-} \mathrm{PO}_{4}\right)$ was determined spectrophotometrically at $690 \mathrm{~nm}$ on a Macherey-Nagel Nanocolor UV / VIS spectrophotometer, with ammonium molybdate and tin (II) chloride. Total phosphorus content was measured using the molybdenum blue method with sample mineralization with sulfuric acid 31:100 and ammonium persulphate. Organic phosphorus was calculated as the difference between the total phosphorus and its mineral form. The concentration of ammonium nitrogen was measured using the Merck test (Merck SQ 118 spectrophotometer). Nitrate nitrogen was examined spectrophotometrically at $410 \mathrm{~nm}$, with the method of phenyldisulfonic acid in an alkaline environment 
Table 1. Morphometric parameters of Lake Mielenko (Department of Water Protection Engineering and Environmental Microbiology- unpublished details)

\begin{tabular}{cccc}
\hline Parameter & Symbol & Unit & Value \\
\hline Water surface area & $\mathrm{A}$ & ha & 7.8 \\
Maximum depth & $\mathrm{H}_{\max }$ & $\mathrm{m}$ & 1.9 \\
Mean depth & $\mathrm{H}_{\text {ave }}$ & $\mathrm{m}$ & 1.3 \\
Relative depth index & $\mathrm{H}_{\text {rel. }}$ & - & 0.0068 \\
Depth index & $\mathrm{Wg}$ & - & 0.68 \\
Water volume & $\mathrm{V}$ & $\mathrm{m} 3$ & 102,900 \\
Maximum length & $\mathrm{D}_{\max }$ & $\mathrm{m}$ & 460 \\
Maximum width & $\mathrm{S}_{\max }$ & $\mathrm{m}$ & 252 \\
Elongation & $\lambda$ & - & 1.8 \\
Mean width & $\mathrm{S}_{\text {ave }}$ & $\mathrm{m}$ & 170 \\
Shoreline length & $\mathrm{L}$ & $\mathrm{m}$ & 1314 \\
Shoreline development index & $\mathrm{K}$ & - & 1.3 \\
\hline
\end{tabular}

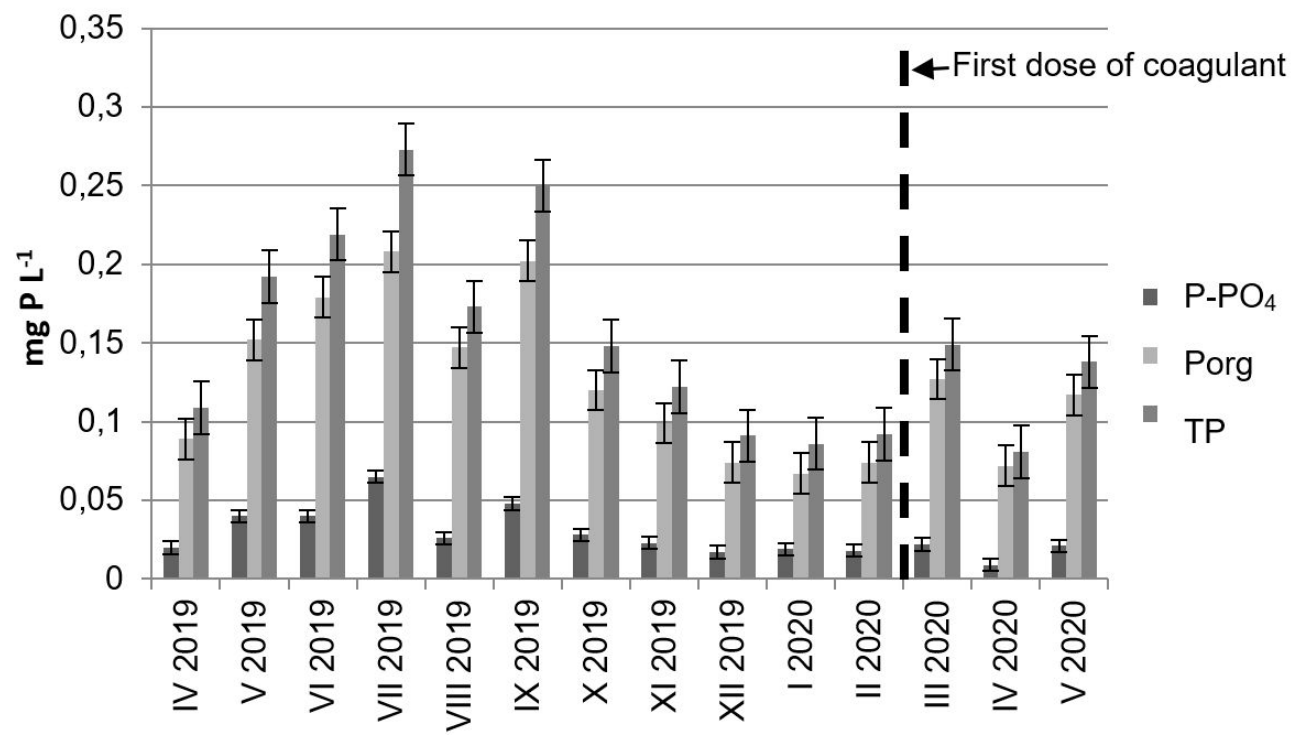

Fig. 2 Concentrations of phosphorus forms in Lake Mielenko along with the standard deviation 


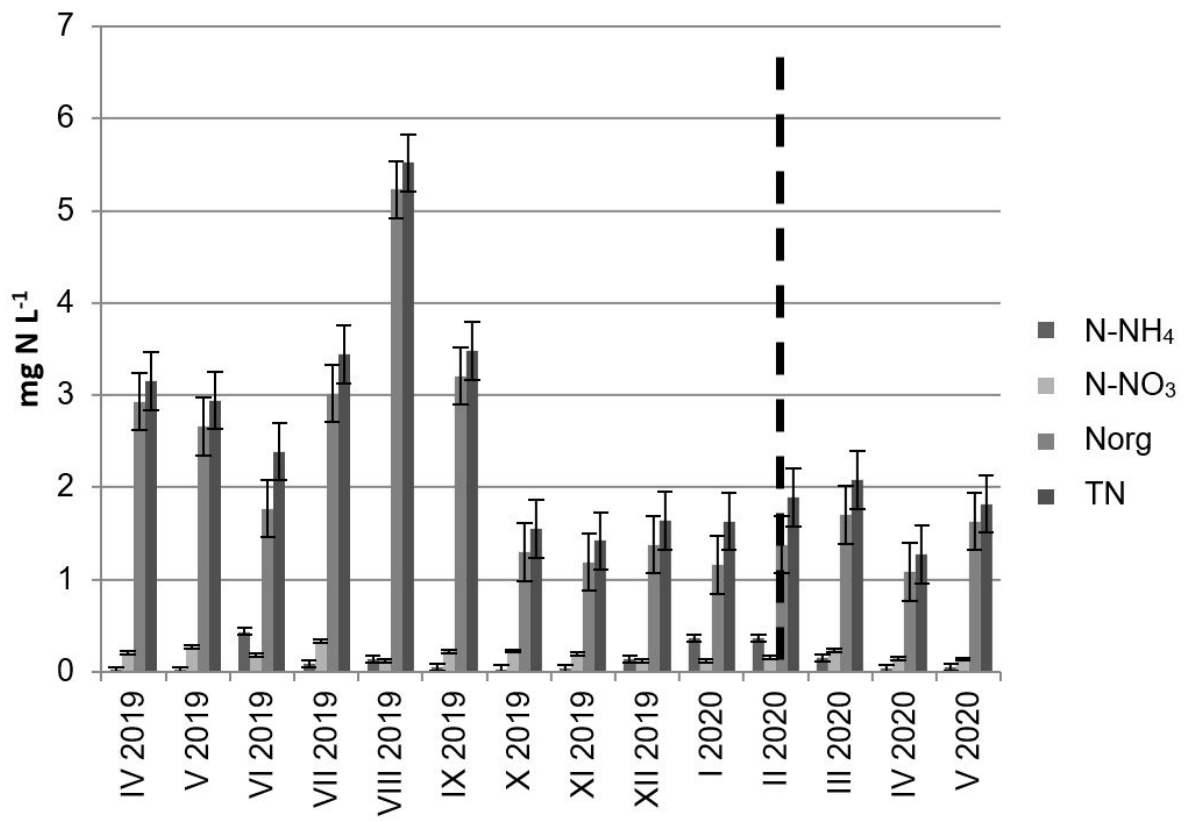

Fig. 3 Concentrations of nitrogen forms in Lake Mielenko along with the standard deviation

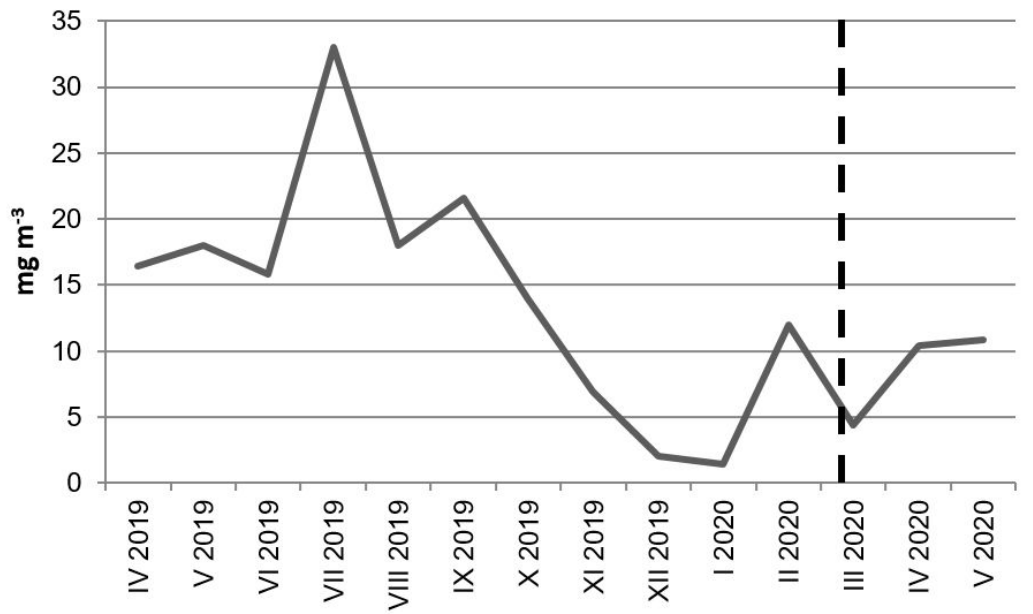

Fig. 4 Changes in the concentration of chlorophyll-a in Mielenko Lake

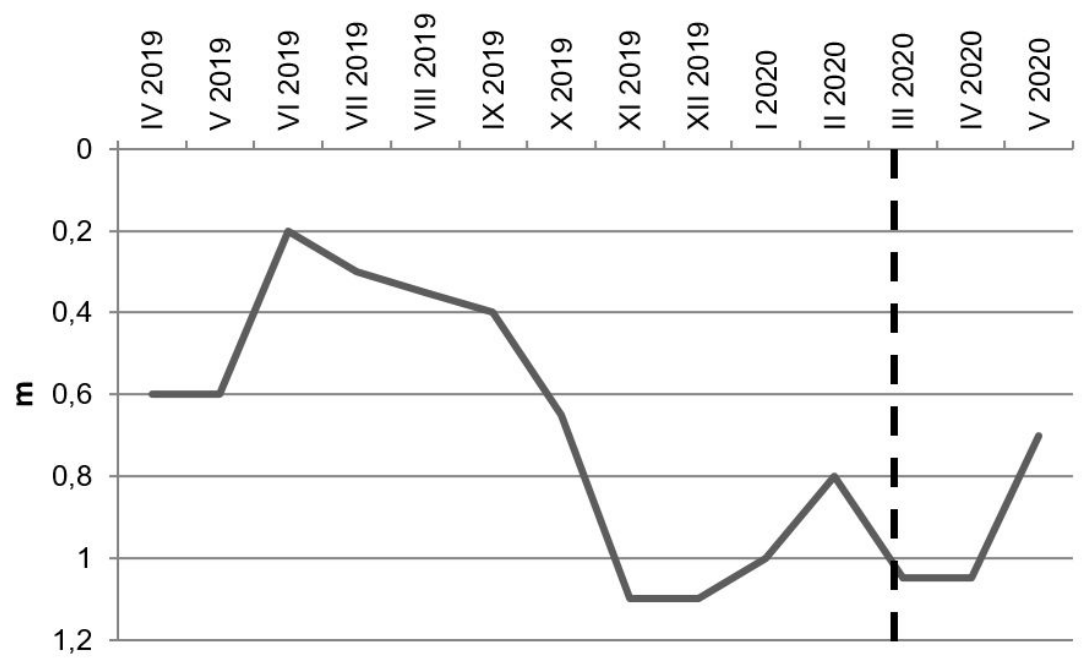

Fig. 5 Changes in visibility in Lake Mielenko 
using a Macherey-Nagel Nanocolor UV / VIS spectrophotometer. Total nitrogen (TN) was determined using an HACH 550 TOC-TN analyzer. The content of organic forms was obtained from the difference between $\mathrm{TN}$ and mineral forms. Chlorophyll-a concentration was determined spectrophotometrically by extraction using acetone and measuring absorbance before and after acidification of the sample with hydrochloric acid after compaction on a Whatman GF / C glass fiber filter. Water transparency was determined using a Secchi disc. The content of nitrite nitrogen in surface waters is an unstable transient form between the ammonium and nitrite forms and because of its low concentration, this indicator was neglected.

Since nitrites (NO3) were not detected in the analyzed water, they were not taken into account in the study.

\section{Results}

During the annual, regular study of Lake Mielenko, it was observed that the main form of nutrients is organic, whose share in total nutrients amounted to 76 $89 \%$ (Fig 2). The lowest values were obtained in winter (December 2019 - February 2020). The total phosphorus concentration in the studied lake ranged from 0.081 - $0.273 \pm 0.01 \mathrm{mg} \mathrm{L}^{-1}$. After using coagulants, the total phosphorus concentration did not exceed $0.15 \pm 0.01$ $\mathrm{mg} \mathrm{P} \mathrm{L} \mathrm{L}^{-1}$. The decrease in phosphorus content is visible compared to the previous year.

Total nitrogen content ranged from 1.27-5.52 \pm 0.1 $\mathrm{mg} \mathrm{N} \mathrm{L}^{-1}$ (Fig. 3). Among all forms of this element, organic form dominated, and its share in TN amounted to $71-95 \%$. The highest values were observed in August 2019, while the lowest was just after the application of the first dose of coagulants (April 2020).

After the application of the first dose of coagulants, a significant decrease in nutrient content was observed compared to the previous year. Only the ammoniacal nitrogen content increased from $0.015 \pm 0.01 \mathrm{mg}$ $\mathrm{L}^{-1}$ in April 2019 to $0.037 \pm 0.02 \mathrm{mg} \mathrm{L}^{-1}$ in April 2020 and from $0.008 \pm 0.01$ to $0.05 \pm 0.01 \mathrm{mg} \mathrm{L}^{-1}$ in May (2019 and 2020, respectively). The concentration of remaining forms of nitrogen decreased. Organic nitrogen showed the highest percentage of reduction in April and amounted to $63 \%$ (from $2.93 \pm 0.08$ to $1.63 \pm 0.05 \mathrm{mg}$ $\left.\mathrm{L}^{-1}\right)$. A significant decrease was also observed for total nitrogen. In April 2020, this indicator was $1.82 \pm 0.05$ $\mathrm{mg} \mathrm{L}^{-1}$, while the year before it was $3.15 \pm 0.1 \mathrm{mg} \mathrm{L}^{-1}$. Among the forms of nitrogen, nitrate nitrogen showed the lowest reduction efficiency in April, amounting to $29 \%$. In May, a much higher degree of reduction of approx. $50 \%$ was observed. For total nitrogen and organic nitrogen, an approx. $40 \%$ decrease in the concentration of these parameters was observed.

The concentration of phosphorus in the months after lake restoration was also much lower compared with the corresponding months of the previous year. The content of total phosphorus decreased by $26 \%$ in April and by $28 \%$ in May. For organic phosphorus, the reduction rate in the analyzed months was similar and amounted to about $20 \%$. The concentration of orthophosphates in April 2019 was $0.02 \pm 0.001 \mathrm{mg} \mathrm{L}^{-1}$ and in the first month after the application of the coagulant it was $0.009 \pm 0.001 \mathrm{mg} \mathrm{L}^{-1}$ (reduction efficiency of 55\%). In May, the content of orthophosphates decreased from $0.04 \pm 0.005 \mathrm{mg} \mathrm{L}^{-1}$ to $0.021 \pm 0.005 \mathrm{mg} \mathrm{L}^{-1}$.

The highest concentrations of chlorophyll-a were observed in summer and the lowest were noted in winter. The highest concentrations were recorded in July $2019\left(33 \pm 0.5 \mathrm{mg} \mathrm{m}^{-3}\right)$. After this time, there was a slow decrease in the content of chlorophyll-a in the water until January 2020, when the lowest value was recorded $\left(1.4 \pm 0.01 \mathrm{mg} \mathrm{m}^{-3}\right)$. After the use of iron and aluminum salts, the content of chlorophyll-a decreased significantly compared with the previous year. In April 2020, the content of chlorophyll-a was $10.4 \pm 0.2 \mathrm{mg} \mathrm{m}^{-3}$. A year earlier, a higher value was recorded $\left(16.4 \pm 0.2 \mathrm{mg} \mathrm{m}^{-3}\right)$. In May 2020, the concentration was $10.8 \pm 0.2 \mathrm{mg} \mathrm{m}^{-3}$, while in 2019 it was $18 \pm 0.4 \mathrm{mg} \mathrm{m}^{-3}$.

The visibility in the studied lake changed seasonally. Low values were observed during summer. During this period, water transparency changed in the range of 0.2-0.4 m. Much higher transparency of the lake was observed during the autumn circulation and in winter $(1.1 \mathrm{~m})$. After the application of the first dose of coagulant, visibility in the tank significantly improved. Sampling in June took place after heavy rainfall, which resulted in an increase in organic matter entering the lake along with the surface runoff. Due to this, the water transparency was only $0.2 \mathrm{~m}$ with a low chlorophyll-a content.

\section{Discussion}

Lake Mielenko is classified as shallow-water lake. According to Olrik (2000), the average depth of such a waterbody as reservoirs is less than $3 \mathrm{~m}$. The maximum depth of the analyzed lake does not exceed $2 \mathrm{~m}$.

Restoring good water status in shallow lakes is 
not a simple task. First, the nutrient load reaching the water body from catchment sources should be reduced as much as possible (Olrik 2000). During protective work, it is possible to achieve a slowdown, stop or even reverse the eutrophication process (Grochowska et al. 2011). In many cases, the reduction of pollutants from the catchment is insufficient. During long-term pollution, biogenic nutrients accumulate in bottom sediments from where they return to the water column in adverse environmental conditions. This is influenced by redox conditions in the bottom zone and the accompanying reduction in the oxidoreductive potential, which initiates the internal loading process (Gawrońska et al. 2003, Dąbrowska and Lejcuś 2012). It is believed that the content of nutrients in bottom sediments is almost inexhaustible. The source of phosphorus and nitrogen, in this case, could initiate the internal loading process and create an ecological disaster for the entire aquatic ecosystem.

Shallow lakes are also exposed to nutrient loading as the result of re-suspension, which leads to a significant increase in nutrients in the water medium (Søndergaard 2007). Lake Mielenko, due to its morphometry, is significantly exposed to the release of nitrogen and phosphorus from bottom sediments.

Very often, the only remedy for such lakes is the use of the technical restoration method. In the case of Lake Mielenko, phosphorus inactivation in bottom sediments using aluminum and iron coagulants (trade names PIX 111 and PAX 18) was implemented. The purpose of this method is to increase the phosphorus binding capacity of the bottom sediment (Ripl 2011), which results in a decrease in the release of this element into the water column (Maehl 2000a).

To ensure or maintain adequate water transparency in shallow lakes, the phosphorus content should be between 0.05 and $0.15 \pm 0.01 \mathrm{mg} \mathrm{P} \mathrm{L}^{-1}$ (Maehl 2000b). Research on the water of Lake Mielenko showed higher values, especially during the summer. High concentrations of nutrients classify the lake as highly eutrophic. The condition of the lake is caused by its supply with nutrients with surface runoff from the direct catchment, the load of nutrients introduced with atmospheric precipitation and intensive recreational use from angling. In the analyzed research period, high levels of phosphorus and nitrogen were observed in the water of Lake Mielenko. Nitrates had the largest share among mineral forms of nitrogen.

Good oxygenation of water and elevated temperature enable the oxidation of ammonium to nitrate compounds. Since nitrite compounds are a transient and unstable form (Grochowska 2001) they were not observed in the analyzed water. According to Grochowska et al. (2015), phosphorus inactivation does not affect the thermal properties of the lake.

The combination of iron and aluminum coagulants caused a significant decrease in the content of mineral phosphorus $\left(\mathrm{P}-\mathrm{PO}_{4}\right)$ in the water column. The efficiency of orthophosphate removal was $48-55 \%$ compared to the previous year. Organic forms were reduced by $19-23 \%$ while total phosphorus was reduced by $26-$ $28 \%$. PIX and PAX coagulants did not decrease ammonia concentration. In the first month after the application of the coagulant dose, the total nitrogen content decreased from $3.15 \pm 0.1$ (in April 2019) to $1.27 \pm 0.1$ (in April 2020). In May 2019, the total nitrogen concentration was $2.94 \pm 0.1$, while in 2020 it was $1.82 \mathrm{mg} \mathrm{L}^{-1}$. This gives a reduction of $60 \%$ and $38 \%$, respectively. High removal efficiency was observed for organic nitrogen in April (63\%) and May (39\%). According to Gawrońska et al. (2001) coagulants have an inhibitory effect on phosphate release from bottom sediment, which is why that reclamation method shows the best results for shallow polymictic lakes (Łopata 2013).

Restoration using iron and aluminum salt coagulants is used quite often. This method is considered the cheapest restoration method (Gawrońska et al. 2003). In Poland, the first lake where phosphorus inactivation was applied was Lake Długie in Olsztyn (2001-2003). After the use of coagulants, a decrease in nitrogen concentration was observed from $22.89 \mathrm{mg} \mathrm{N} \mathrm{L}^{-1}$ to approx. $3.4 \pm 0.2 \mathrm{mg} \mathrm{N} \mathrm{L}^{-1}$ (Grochowska et al. 2015). On the other hand, the concentration of total phosphorus decreased from $0.079 \pm 0.085 \mathrm{mg} \mathrm{P} \mathrm{L}^{-1}$ to $0.001 \pm 0.003$ mg P L-1 (Grochowska et al. 2013). In Lakes Głęboczek (in Tuchola) and Wolsztyńskie (in Wolsztyn), the phosphorus concentration dropped to approx. 0.1-02 mg P $\mathrm{L}^{-1}$ (Gawrońska et al. 2007).

Restoration carried out on the Gross-Glienicker lake (Germany) resulted in a reduction of phosphorus from $0.5 \mathrm{mg} \mathrm{P} \mathrm{L}^{-1}$ to about $0.03-0.04 \mathrm{mg} \mathrm{P} \mathrm{L}^{-1}$. Visibility in the lake increased significantly, which caused the development of submerged vegetation (Wolter 2010). On Lake Lyngby, the effectiveness of the method in reducing phosphorus was estimated at $60 \%$, and the transparency of the water column increased by $0.45-0.6 \mathrm{~m}$. However, this was a temporary effect due to an excessively high external load (Maehl. 2000).

Welch and Cooke (2009) describe the effectiveness of phosphorus inactivation with aluminum sul- 
phate. In all analyzed lakes (21 lakes), the total phosphorus content decreased by half. In polymictic lakes, chlorophyll-a decreased by $2 / 3$ of the value before restoration. The durability of the method in terms of phosphorus content was estimated at 5-11 years. In some lakes, the duration of the method was estimated at 1318 or even up to 20 years.

So-called 'water blooms' were a common phenomenon observed in the lake due to the occurrence of phytoplankton from early spring to late autumn (Sidorczuk, Potasznik 2011). High concentrations of nutrients had an impact on this phenomenon. High primary production was confirmed by chlorophyll-a concentration. The highest values were obtained in summer 2019 (15.8-33.0 $\pm 0.3 \mathrm{mg} \mathrm{m}^{-3}$. In the autumn and winter period, a significant decrease in chlorophyll-a content down to $2.0 \pm 0.3 \mu \mathrm{g} \mathrm{L}^{-1}$ was noted. In spring there was a slight increase in the concentration of the analyzed parameter. It was affected by the application of coagulants. Due to the limited availability of nutrients, the primary production process was reduced, which resulted in a reduction in chlorophyll-a content, followed by a significant improvement in visibility (Wolter 2010).

Based on the presented research, it can be concluded that Lake Mielenko is a eutrophic lake. The high content of biogenic compounds contained in the water column was reflected in the content of chlorophyll-a, and thus adversely affected the transparency of the water. The first dose of coagulants used on the lake significantly reduced the nutrients in the water column, and significantly decreased chlorophyll-a concentration and, thus, improved water transparency in the lake.

\section{Acknowledgments}

The author would like to express gratitude to $\mathrm{dr}$ hab inż. Jolanta Grochowska, prof. UWM and dr hab inż. Renata Augustyniak for their substantive support and all valuable tips. I also thank all the employees of the Department of Water Protection Engineering and Environmental Microbiology for their help in carrying out the research.

\section{Reference}

Dąbrowska J., Lejcuś K., 2012, Characteristics of Bottom Sediments of the Dobromierz Reservoir, Kraków, Polish Academy of Sciences, 3 (4), 89-98.

Gawrońska H., Lossow K., Łopata M., 2003, Lakes methods of protection and restoration with particular emphasis on Lake Głęboczek in Tuchola, Develop- ment for teaching purposes, UWM in Olsztyn.

Grochowska J. Karpienia M., Tandyrak R., 2011, Water chemistry and the concept of protecting a lake under agricultural pressure, Acta Sci. Pol., Formatio Circumiectus 10 (3): 21-30.

Hermanowicz W., Dojlido J., Dożańska W., Koziorowski B., Zerbe J., 1999, Physico-chemical analysis of water and sewage. Warsaw, Ed. Arkady.

Jachniak E., 2013, Biogenic compounds and the process of eutrophication of the waters of the Goczalkowice water reservoir, Cracow, Polish Academy of Sciences, 3:31-48

Kajak Z., 2001, Hydrobiology- Limnologia, Warsaw, PWN Scientific Publishing House.

Łopata M., 2013, Lake Reclamation - Methods, Conditions, Action Stages, Domagała J., Czerniawski R, Pilecka-Rapacz M. [in:] Anthropopression on Aquatic Ecosystems and Nature Conservation and Activation of Fisheries. University of Szczecin, Barlinek: 61-83

Maehl R., 2000 b, 2000, Lake reclamation - practical methods for estimating and reducing phosphorus load from the lake catchment area [in:] Giziński A., Burak S., Protection and restoration of lakes, Przysiek: 173-180

Maehl R., 2000 a: A Guide to Lake Remediation for the Sonderjylland Province. Ramboll Danemark, Tonder, 15-20.

Olrik K., 2000, Protection of shallow lakes in Denmark [in:] Giziński A., Burak S., Protection and restoration of lakes, Przysiek: 41-56

Sidoruk M., Potasznik A., 2011, The Trophic status of Symsar lake and possibilites of approvement, Ecological Engineering, 26:221-229

Siwek H., 2013, Systemic Approach to Eutrophied Aquatic Ecosystem, Domagała J., Czerniawski R, Pilecka-Rapacz M. [in:] Anthropopression on Aquatic Ecosystems and Nature Conservation and Activation of Fisheries. University of Szczecin, Barlinek:

Sřndergaard M., 2007, Nutrient Dynamics In Lakes - With Emphasis On Phosphorus, Sediment And Lake Restoration, National Environmental Research Institute

Grochowska J., 2001, Możliwości odnowy silnie zdegradowanych jezior metodą wieloletniego sztucznego napowietrzania na przykładzie jeziora Długiego w Olsztynie, praca doktorska, UWM Olsztyn

Grochowska J., Brzozowska R., Łopata M., Dunalska J. 2015. Influence of restoration methods on the longevity of changes in the thermal and oxygen dynamics of a degraded lake. Oceanological and Hydrobioogical Studies, 44(1):1-10

Grochowska J., Brzozowska R., Łopata M., 2013, Durability of changes in phosphorus compounds in water of an urban lake after application of two reclamation methods. Water Science \& Technology, 1: 234-239

Ripl W., 2011, Restoration of Eutrophic Lakes by Sediment Treatment, [in:] Eiseltová M., Restoration of Lakes, Streams, Floodplains, and Bogs in Europe - 
Principles and Case Studies, Springer, Australia, 7784.

Gawrońska H., Łopata M, Jaworska B., 2007, The effectiveness of the phosphorus inactivation method in reducing the trophy of lakes of different morphometric and hydrological features, Limnol. Rev. 1: 27-34

Hickey C., Gibbs M., 2009, Lake sediment phosphorus release management-Decision support and risk assessment framework, Research Gate, 43: 819-856

Wolter K., Restoration of Eutrophic Lakes by Phosphorus Precipitation, with a Case Study on Lake Gross-Glienicker, 2010, [in:] Eiseltová M., Restoration of Lakes, Streams, Floodplains, and Bogs in Europe - Principles and Case Studies, Springer, Australia, 3:85-99 